\title{
Dynamics of Heavy Rain Spells over India during 2005
}

\author{
S. S. Naik ${ }^{1}$, P. S. Salvekar ${ }^{2}$ \\ ${ }^{1}$ Indian Institute of Tropical Meteorology, Dr. Homi Bhabha Road, Pashan, Pune-411007, India \\ 2341, Narayan Peth, Pune-411030, India
}

\begin{abstract}
High-impact mesoscale weather events, occurring in different parts of India in all seasons, lead to major weather and climate related disasters. In view of this, an attempt has been made in the present study to understand the dynamics of atmospheric circulation over the Indian region $\left(50^{\circ} \mathrm{E}-100^{\circ} \mathrm{E}\right.$ and $\left.\mathrm{EQ}-30^{\circ} \mathrm{N}\right)$ during super active monsoon period $21^{\text {st }}-30^{\text {th }} \mathrm{June}$ and $22^{\text {nd }}-31^{\text {st }} \mathrm{July}$ 2005 using NCEP/NCAR reanalyzed daily winds ( $u$ and $v)$, temperature (T) from surface to 200 hPa to compute the divergence (D), vorticity $(\zeta)$, vertical velocity $(\omega)$,static stability $(\sigma)$ and heat source $\left(Q_{H}\right) . \sigma^{-1}(p)$ profiles clearly indicate the unstable zone between 850 to $650 \mathrm{hPa}$. The necessary condition of barotropic instability and condition of baroclinic instability are also satisfied in the layer 850$650 \mathrm{hPa}$ for all the active monsoon days. Further, zonal $(u)$ and meridional $(v)$ winds, are examined in the zonal $(x-p)$ and meridional $(y-p)$ planes. It is noticed that there exist low level cyclonic circulations in the boundary layer over major portion of the country and abnormal increase in the meridional wind in the lower and middle troposphere. Significant increase in the cyclonic vorticity upto 300 hPa and the upward motion throughout in the troposphere with maximum value around 700 to 500 hPa and positive heat source explain the possibility of highly convective and unstable mid-tropospheric zone. The study indicates that there are few mesoscale systems embedded in the synoptic scale system that are already present in the large-scale monsoon circulation.
\end{abstract}

Keywords: Heavy rain spell, Dynamic instability, Mid-tropospheric cyclone, Cubic spline technique, Summer monsoon

\section{Introduction}

Onset of southwest monsoon during 2005 over Kerala coast was declared by India Meteorological Department (IMD) on $5^{\text {th }}$ June and withdrawal from northwest region took place on $2^{\text {nd }}$ September. The initial phase was rather weak but monsoon activity is improved by the third week of June. Due to the intense monsoon activity in the last week of June, monsoon rainfall covered entire country on $30^{\text {th }}$ June i.e. two weeks prior to the normal date. As the onset date varies, atmospheric circulation pattern also differs from year to year. Many studies are available in literature, ( Ananthakrishnan et al [1] \& Joseph et al [2] ) describing the changes that take place in the atmosphere over the Indian sub-continent at the time of onset of monsoon.

During 2005 monsoon, another occasion of heavy rainfall event was found in the last week of July. The detail discussion on the active and break spells of Indian summer monsoon given by Rajeevan et al. [3] reported the active period of monsoon 2005 as $1^{\text {st }}-4^{\text {th }}$ July and $27^{\text {th }}$ July- $1^{\text {st }}$ August. The GCM study by Dey et al. [4] also examined the super active monsoon period $27^{\text {th }}$ July $-1^{\text {st }}$ August 2005. Rajeevan et al. [3] have shown that the rainfall enhancement during active monsoon can last from a few days to beyond a week. It is important to note that the total monsoon duration of 2005 was 90 days (onset 5 August and withdrawal $2^{\text {nd }}$ September) which was much less than normal 120 days. But still overall seasonal rainfall amount for the country as a whole was good for the monsoon year 2005. In fact, temporal distribution of rainfall was below normal in nine weeks in large part of the country out of seventeen monsoon weeks. Most of the subdivision reached normal rainfall only because of the abnormal monsoon behavior in the last two pentads of June $\left(21^{\text {st }}-30^{\text {th }}\right.$ June $)$ and July $\left(22^{\text {nd }}-31^{\text {st }}\right.$ July $)$ when there were very heavy rain spells in the western part of the country. Due to these heavy spells, the total rainfall activity became normal over west of $80^{\circ} \mathrm{E}$. On $26^{\text {th }} \mathrm{July}$, there was abnormally intense rainfall $(994 \mathrm{~mm}$ ) at Mumbai and many west coast stations also received excessive rainfall during the last week of July.

Many observational and simulation studies are available in the literature [5-11] for understanding the record heavy rainfall events over Mumbai on $26^{\text {th }} \& 27^{\text {th }}$ July 2005. Francis et al [12] examined the incidence of such events along the west coast of India and found that the belt between $14^{\circ} \mathrm{N}$ and $20^{\circ} \mathrm{N}$ is especially susceptible to such events, which occur as a result of several factors such as the largescale strengthening of the monsoon winds over the Arabian Sea, the movement of monsoon depressions from the Bay of Bengal to central India along approximately $20-22^{\circ} \mathrm{N}$, the formation of mid-tropospheric cyclones (MTCs) and the presence of active off shore troughs in the lower troposphere along central and northern parts of the coast with the possibility of an embedded mesoscale cyclonic circulation. De et al [13] have studied the role of enhancement of convective available potential energy (CAPE) and decrease in convective inhibitive energy (CINE) in the incidence of very heavy rainfall at Mumbai. Ranade et al [14] have also evaluated severity of the $26^{\text {th }}-27^{\text {th }}$, July 2005 rainstorm over Mumbai in the backdrop of fluctuations of the spatiotemporal 1-DSG (degree square grid) extreme rainfall over the country and their investigation reveals that occurrence of unprecedented rainfall is a realization of highly significant increasing trend in the spatio-temporal extreme rainfall over the country. In the past, Ramage [15] reviewed studies of heavy tropical rainfalls and concluded that the heavy rainfalls are associated with the thunderstorms. These storms are embedded in the synoptic scale disturbances. In the 


\section{International Journal of Science and Research (IJSR) \\ ISSN (Online): 2319-7064}

Index Copernicus Value (2013): 6.14 | Impact Factor (2013): 4.438

present study, dynamics of the heavy rain spells over the Indian region $\left(50^{\circ} \mathrm{E}-100^{\circ} \mathrm{E}\right.$ and $\left.\mathrm{EQ}-30^{\circ} \mathrm{N}\right)$ have been explored for last two pentads of June and July during $21^{\text {st }}$ $30^{\text {th }}$ June and $22^{\text {nd }}-31^{\text {st }}$ July of 2005 monsoon. For this purpose, dynamical (D, $\zeta$ and $\omega$ ) and physical $\left(\mathrm{Q}_{\mathrm{H}}\right)$ parameters, meridional gradient of absolute vorticity, static stability $\sigma(p)$ and meridional gradient of potential vorticity $\mathrm{Q}_{\mathrm{y}}(\mathrm{p})$ as well as the occurrence of strong horizontal and vertical wind shear are computed.

\section{Propagation of summer monsoon during 2005}

The southwest monsoon during 2005 reached south Andaman Sea and parts of southeast Bay on $26^{\text {th }}$ May, with a delay of about 6 days. The Arabian Sea branch started advancing on $5^{\text {th }}$ June and the onset was declared on $5^{\text {th }}$ June over Kerala. Thereafter, monsoon propagation is rather weak. However, a monsoon depression formed in the Arabian Sea as well as in Bay of Bengal during last week of June that leads to the advancement of monsoon throughout the country by $30^{\text {th }}$ June. During July, again monsoon activity was weakened which shows deficient monsoon activity till the $3^{\text {rd }}$ week of July. Due to the occurrence of depression over Orissa coast, in the last week of July, heavy rainfall occurred in most of the sub-division over Indian region. These systems are responsible to make the all India rainfall activity as normal.

\section{Data and Methodology}

The unusual heavy spells of rainfall activities are studied by examining dynamical $(\mathrm{D}, \zeta$ and $\omega)$ and physical $\left(\mathrm{Q}_{\mathrm{H}}\right)$ parameters during the period $21^{\text {st }}-30^{\text {th }}$ June and $22^{\text {nd }}-31^{\text {st }}$ July, using NCEP/NCAR reanalyzed (Kalnay et al [16]) daily zonal and meridional wind $(\mathrm{u}$ and $\mathrm{v})$, temperature $(\mathrm{T})$ and relative humidity (q) data from surface to $200 \mathrm{hPa}$, over the region $50^{\circ} \mathrm{E}-100^{\circ} \mathrm{E}$ and $\mathrm{EQ}-30^{\circ} \mathrm{N}$. To determine the instability characteristics of large-scale monsoon circulation, the static stability $[\sigma(p)]$ and meridional gradient of potential vorticity $\left[\mathrm{Q}_{\mathrm{y}}(\mathrm{p})\right]$ and meridional gradient of absolute vorticity $\mathrm{Q}_{\mathrm{y}}(\mathrm{y})$ are also computed throughout the period mentioned above. Further, wind shear in the $x-p$ plane $\left(15^{\circ} \mathrm{N}\right)$ and $y-p$ plane $\left(80^{\circ} \mathrm{E}\right)$ are also examined over the domain.

Vertical component of relative vorticity $(\zeta=\partial v / \partial x-\partial u / \partial y)$ and horizontal divergence $(D=\partial u / \partial x+\partial v / \partial y)$ are the two important parameters for understanding the dynamics of the system. Negative divergence i.e. $-(\partial u / \partial x+\partial v / \partial y)$ is called convergence and positive vorticity means cyclonic circulation

From the direction and magnitude of vertical velocity $(\omega)$, the atmospheric situation can be diagnosed. Therefore, vertical velocity $(\omega)$, is computed using kinematic method. This method assumes that total divergence is zero in the unit vertical column, so a correction factor as given by $\mathrm{O}^{\mathrm{e}} \mathrm{Brien}$ [17] is introduced to get correct , $\omega^{\text {ee }}$. All the computations are carried out at $50 \mathrm{hPa}$ interval for which the data is interpolated using cubic spline technique [18]. Vertical velocity contributes significantly in the heat and moisture budget during convective activity. The heat budget $\left(Q_{\mathrm{H}}\right)$ is obtained by using,

$Q_{H}=C_{p}\left[\frac{\partial T}{\partial t}+u \frac{\partial T}{\partial x}+v \frac{\partial T}{\partial y}+\omega\left(\frac{\partial T}{\partial p}-\frac{R T}{C_{p} p}\right)\right\rfloor$

and static stability $\sigma$ is obtained from

$[\sigma(p)]=-\frac{R}{p}\left[\frac{\partial \bar{T}}{\partial p}-\frac{R \bar{T}}{C_{p} p}\right]$

The meridional gradient of potential vorticity $\left[\mathrm{Q}_{\mathrm{y}}(\mathrm{p})\right]$ for combined zonal and meridional flow [19] is computed by using.

$$
\left[Q_{y}(p)\right]=\beta-f_{o}^{2} \frac{\partial}{\partial p}\left\{\frac{1}{\sigma} \frac{\partial}{\partial p}\left([u]+\frac{\ell}{k}[v]\right)\right\}
$$

And the meridional gradient of absolute vorticity of zonal flow is given by

$$
\bar{Q}_{y}(y)=\beta-\bar{u}_{y y}
$$

where $\mathrm{R}=287, \mathrm{Cp}=1004 \mathrm{~J} \mathrm{~kg}^{-1} \mathrm{k}^{-1}, \mathrm{k}$ and $\ell$ are zonal and meridional wave number, over the domain $50^{\circ} \mathrm{E}-100^{\circ} \mathrm{E}$ and EQ- $30^{\circ} \mathrm{N}$ respectively. $\mathrm{f}_{\mathrm{o}}$ and $\beta$ are considered for $15^{\circ} \mathrm{N}$, the central latitude of the region, over bar denotes zonally averaged value and [ ] denotes area average values over the region.

Vertical profiles of $[\sigma(p)]$ and $\left[Q_{y}(p)\right]$ as well as meridional profile of $\mathrm{Q}_{\mathrm{y}}(\mathrm{y})$ are obtained for each day from $21^{\text {st }}-30^{\text {th }}$ June and $22^{\text {nd }}-31^{\text {st }}$ July. It is important to note that changing the sign of $\left[Q_{y}(p)\right]$ in the vertical domain is the necessary condition of baroclinic instability [20] and necessary condition for barotropic instability is that $\mathrm{Q}_{\mathrm{y}}(\mathrm{y})$ must vanish somewhere in the meridional domain. Also we know that in a stable atmosphere $\left[\sigma^{-1}(p)\right]$ decreases exponentially with height.

\section{Results and Discussion}

Dynamic instability characteristics are studied throughout the period from $21^{\text {st }}-30^{\text {th }}$ June and $22^{\text {nd }}-31^{\text {st }}$ July by analyzing the vertical profiles of zonal $[\mathrm{u}]$ and meridional $[\mathrm{v}]$ wind, inverse static stability $(\sigma)$ and meridional gradient of potential vorticity $\left[\mathrm{Q}_{\mathrm{y}}(\mathrm{p})\right]$ as well as meridional profile of $\left(Q_{y}(y)\right)$.

\subsection{Period $21^{\text {st }}-30^{\text {th }}$ June}

Day to day winds throughout in the troposphere during $21^{\text {st }}$ $30^{\text {th }}$ June indicate low level westerly and upper level easterly with a transition at about $500-400 \mathrm{hPa}$. The westerly maximum is about $7-8 \mathrm{~ms}^{-1}$ near to $900 \mathrm{hPa}$ and maximum easterly value at $200 \mathrm{hPa}$ is $12 \mathrm{~ms}^{-1}$ noticed throughout the 
period. Meridional winds are weak throughout in the vertical domain except in the boundary layer $(1000-850 \mathrm{hPa})$ where southerly winds have magnitude about $2-3 \mathrm{~ms}^{-1}$.
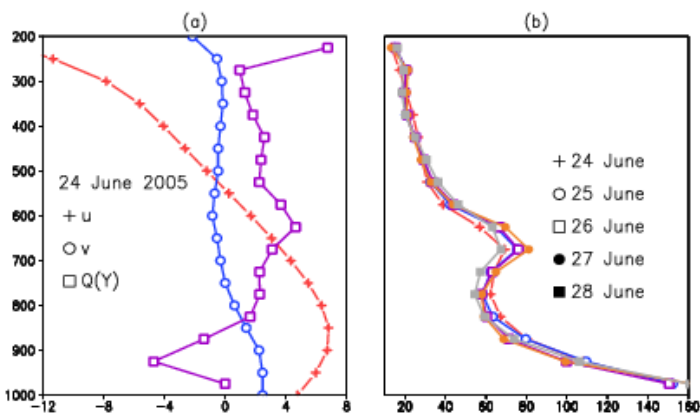

(c)

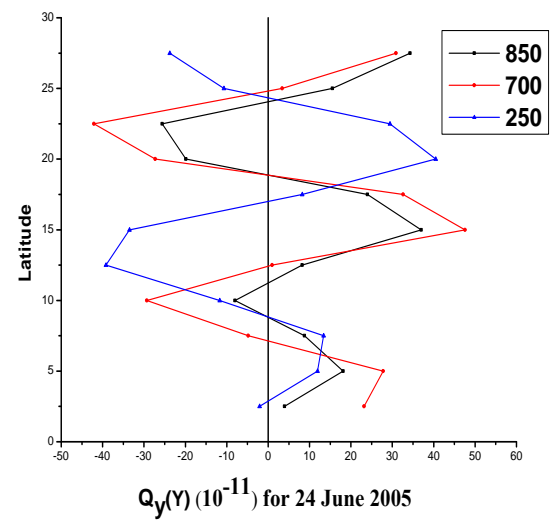

Figure 1: (a) vertical profile of $[\mathrm{u}],[\mathrm{v}]$ and, $\left[\bar{Q}_{y}(p)\right]$, (b) Vertical profile of inverse static stability, (c) Meridional profile of $\left[\bar{Q}_{y}(y)\right]$ at $850 \mathrm{hPa}, 700 \mathrm{hPa}$ and $250 \mathrm{hPa}$ levels for June 2005

The existence of strong wind shear and change of sign in $\left[\mathrm{Q}_{\mathrm{y}}(\mathrm{p})\right]$ in the vertical domain $900-600 \mathrm{hPa}$ together indicates the importance of baroclinic mechanism (Figure 1 (a)), The vertical profile of $\sigma^{-1}$ indicate that the mid-tropospheric layer between $850-650 \mathrm{hPa}$ is unstable for the period $24^{\text {th }}-$ $28^{\text {th }}$ June (Figure 1 (b)), responsible for the occurrence of synoptic system i.e. the depression during $22^{\text {nd }}-27^{\text {th }}$ June. In the past, Mak [21] found the role of baroclinic instability to explain the Mid-tropospheric cyclone. Moorthi et al [22] have shown the reasons of formation of monsoon depression as baroclinic instability mechanism with cumulus heating. Necessary condition of barotropic instability (Figure 1(c)) is found to be satisfied in the peninsular region (near $7.5 \mathrm{~N}$ ) and in the central Indian region (near $18^{\circ} \mathbf{N}$ to $24^{\circ} \mathrm{N}$ ) in the lower and upper troposphere. From the observations, it is found that there exist deep depression during $22^{\text {nd }}-24^{\text {th }}$ June in Arabian Sea and $27^{\text {th }}-30^{\text {th }}$ June in Bay of Bengal. These two systems together lead the monsoon activity very intense throughout the country. From the zonal and meridional winds in the $x-p\left(15^{\circ} \mathrm{N}\right)$ and $y-p\left(80^{\circ} \mathrm{E}\right)$ plane (Figure 2(a) and 2(b)), it is noticed that there are small scale cyclonic circulations in the boundary layer. Maximum zonal wind of about $15 \mathrm{~m} \mathrm{~s}^{-1}$ is seen at $5^{\circ} \mathrm{N}-15^{\circ} \mathrm{N}$ belt on $24^{\text {th }}$ June. (a)

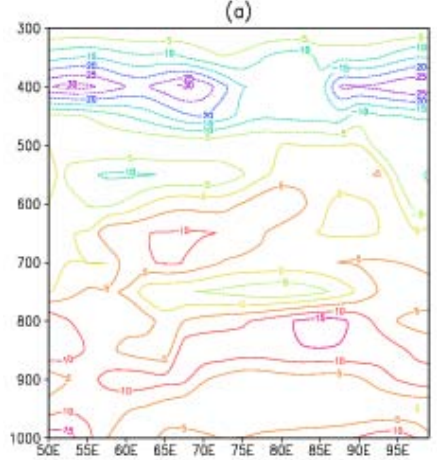

(c)

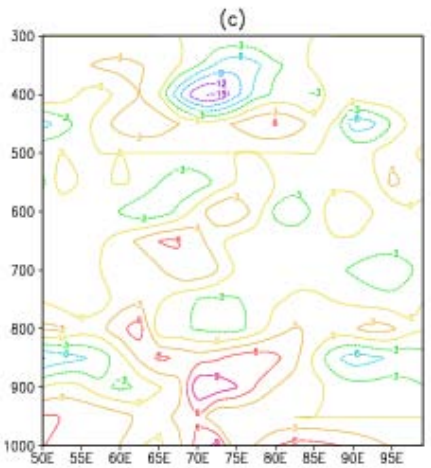

(b)

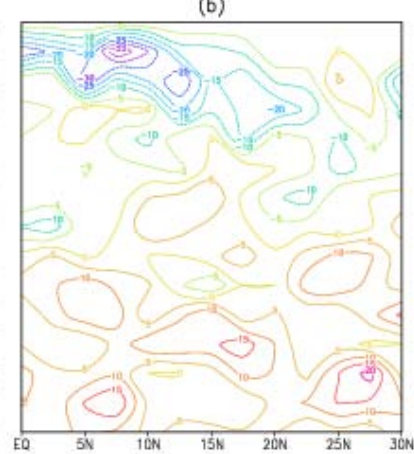

(d)

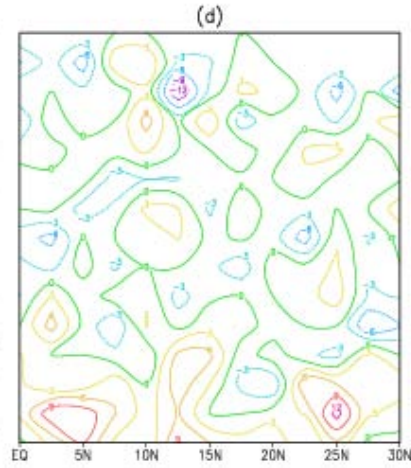

Figure 2 . Vertical distribution of horizontal wind at $15^{\circ} \mathrm{N}$ (x-p plane) and $80^{\circ} \mathrm{E}$ (y-p plane), (a) and (b) for zonal wind, (c) and (d) for meridional wind for $24^{\text {th }}$ June 2005

Reduction in the wind magnitude near surface is seen, that may be due to strong surface friction. Further, careful examination of wind distribution indicates presence of inversion near west coast south of $10^{\circ} \mathrm{N}$. Such situation is noticed for all the days. By examining the dynamical and physical parameters, low level convergence from surface to $700 \mathrm{hPa}$ and upper level divergence is found during the period $22^{\text {nd }}-24^{\text {th }}$ June (figure not shown). In fact, the computations are carried out for every $50 \mathrm{hPa}$ interval; the vorticity $(\zeta)$, divergence (D), vertical velocity $(\omega)$ and heat source $\left(\mathrm{Q}_{\mathrm{H}}\right)$ for $24^{\text {th }}$ June alone are shown for $700 \mathrm{hPa}$ in
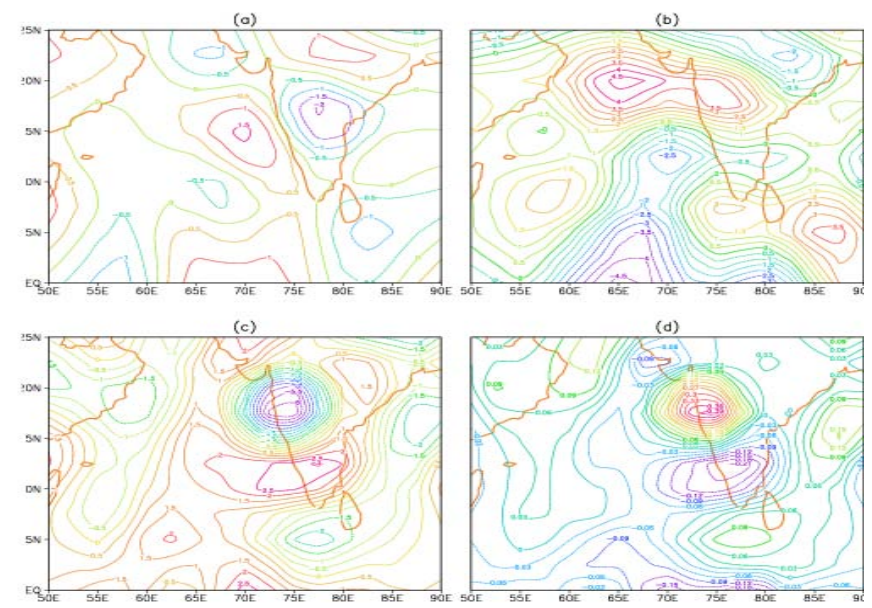

Figure 3: Horizontal distribution of (a) $\mathrm{D}\left(10^{-5} \mathrm{~s}^{-1}\right)$, (b) $\zeta\left(10^{-5} \mathrm{~s}^{-1}\right)$, (c) $\omega\left(10^{-3} \mathrm{hPa} \mathrm{s}^{-1}\right)$ and (d) $\mathrm{Q}_{\mathrm{H}}\left(10^{-1} \mathrm{~J} \mathrm{Kg}^{-1} \mathrm{~s}^{-1}\right)$ at $700 \mathrm{hPa}$ for $24^{\text {th }}$ June 2005 
(Figure 3). Strong upward motion $\left(\omega \sim-7 \times 10^{-3} \mathrm{hPa} \mathrm{s}^{-1}\right)$ significant cyclonic circulation $\zeta\left(\sim 4 \times 10^{-5} \mathrm{~s}^{-1}\right)$ and positive heat source $\left(\mathrm{Q}_{\mathrm{H}} \sim 0.4 \times 10^{-1} \mathrm{~J} \mathrm{~kg}^{-1} \mathrm{~s}^{-1}\right)$ from surface to 400 $\mathrm{hPa}$ gives the indication of heavy precipitation in most of the subdivision west of $80^{\circ} \mathrm{E}$.

\subsection{Period $22^{\text {nd }}-31^{\text {st }}$ July}

Area averaged zonal and meridional wind from $22^{\text {nd }}-31^{\text {st }}$ July are examined. Low level westerly maximum $\left(7-8 \mathrm{~m} \mathrm{~s}^{-1}\right)$ at $850 \mathrm{hPa}$ and upper level easterly maximum (11-12 $\left.\mathrm{m} \mathrm{s}^{-1}\right)$ at $250 \mathrm{hPa}$ is seen in most of the days. Meridional winds are weak throughout the period. The vertical profiles of $[\mathrm{u}],[\mathrm{v}]$ $\left[\mathrm{Q}_{\mathrm{y}}(\mathrm{p})\right]$ and for $26^{\text {th }}$ July are shown in (Figure 4(a)). The vertical profile of $\sigma^{-1}$ computed for each day and it is found that the mid-tropospheric layer from $850-650 \mathrm{hPa}$ are unstable for the period $24^{\text {th }}-28^{\text {th }}$ July (Figure 4(b)). The vertical profile of $\left[\mathrm{Q}_{\mathrm{y}}(\mathrm{p})\right]$ also indicates that the atmosphere is unstable in the lower troposphere. Necessary condition of barotropic instability is found to be satisfied near $18 \mathrm{~N}$ in the lower and upper tropospheric levels. Also $\left[Q_{y}(\mathbf{y})\right]$ profile of $250 \mathrm{hPa}$ changes sign in the peninsular region near $10^{\circ} \mathrm{N}$ (Figure 4(c)).. Magnitudes of zonal wind are found upto $20 \mathrm{~m} \mathrm{~s}^{-1}$ at $15^{\circ} \mathrm{N}$ from $60^{\circ} \mathrm{E}-95^{\circ} \mathrm{E}$ around $850 \mathrm{hPa}$ on $26^{\text {th }}$ July (Figure 5(a)). Further meridional winds are found intense with magnitude $\left(\sim 10-15 \mathrm{~m} \mathrm{~s}^{-1}\right)$ upto $600 \mathrm{hPa}$ east of $65^{\circ} \mathrm{E}$ as seen in Figure 5(c). In the y-p plane from $5^{\circ} \mathrm{N}$ $20^{\circ} \mathrm{N}$ and the zones of southerly and northerly winds are noticed at the interval of $5^{\circ} \mathrm{N}$ (Figure 5(d)). This suggests strong meridional shear of meridional wind. Magnitude of $\partial \mathrm{v} / \partial \mathrm{y}$ is large, i.e.1.4 $\times 10^{-6} \mathrm{~s}^{-1}$. At the same time, the eastwest shear of zonal wind is very small. Role of strong surface friction around $15^{\circ} \mathrm{N}-20^{\circ} \mathrm{N}$ and inversion at $5^{\circ} \mathrm{N}-6^{\circ} \mathrm{N}$ are seen in the y-p plane distribution of zonal wind along $80^{\circ} \mathrm{E}$ on $26^{\text {th }}$ July (Figure 5(b)). It indicates that the core of westerly maximum wind is sloping from $800 \mathrm{hPa}$ at $6^{\circ} \mathrm{N}$ to $950 \mathrm{hPa}$ at $27^{\circ} \mathrm{N}$. The isolines of $\zeta, \mathrm{D}, \omega$ and $\mathrm{Q}_{\mathrm{H}}$ are presented in (Figure 6) for $26^{\text {th }}$ July at $700 \mathrm{hPa}$. There exist large convergence (negative divergence) resulting significant upward motion near $15^{\circ} \mathrm{N}, 80^{\circ} \mathrm{E}$ at $700 \mathrm{hPa}$. This fact is clearly seen from (Figure 6(c)). By examining the isolines of $\zeta$ and $\omega$, for different vertical levels, eastward tilt in the vertical is clearly seen from the zones of upward motion. This supports the baroclinic mechanism for the synoptic scale monsoon depression which is present during the period. In the west coast, the isolines of $\zeta$ show maximum intensity at about $700 \mathrm{hPa}$ with weak circulation at surface level indicates the presence of Mid-Tropospheric Cyclone (MTC) near Mumbai and Gujarat coast during $23^{\text {rd }}$ to $26^{\text {th }}$ July. Combined effect of off shore vortex, monsoon depression and MTC resulted excessive rainfall in the west of $80^{\circ} \mathrm{E}$.
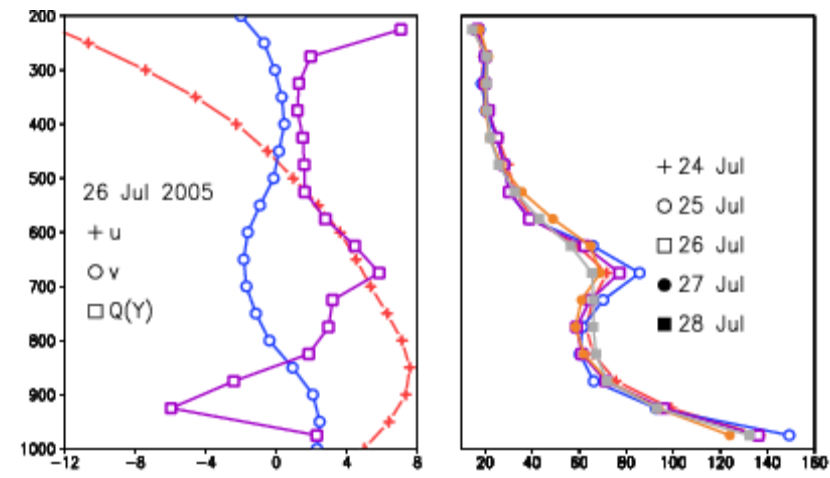

a)

(b)

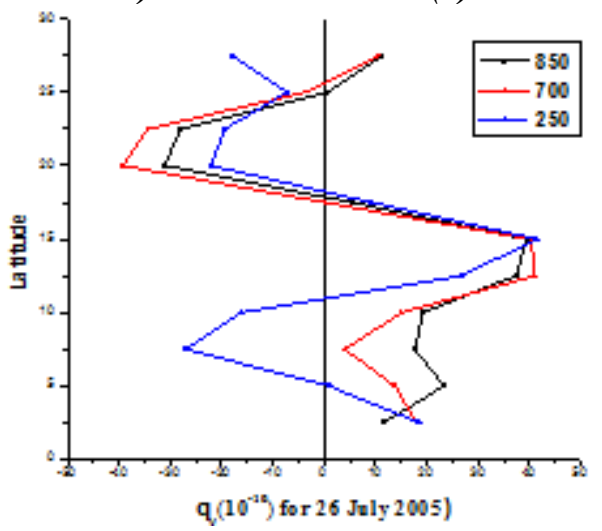

Figure 4: (a) vertical profile of $[\mathrm{u}],[\mathrm{v}]$ and, $\left[\bar{Q}_{y}(p)\right]$ (b) Vertical profile of inverse static stability,(c) Meridional profile of $\left[\bar{Q}_{y}(y)\right]$ at $850 \mathrm{hPa}, 700 \mathrm{hPa}$ and $250 \mathrm{hPa}$ levels for July 2005.
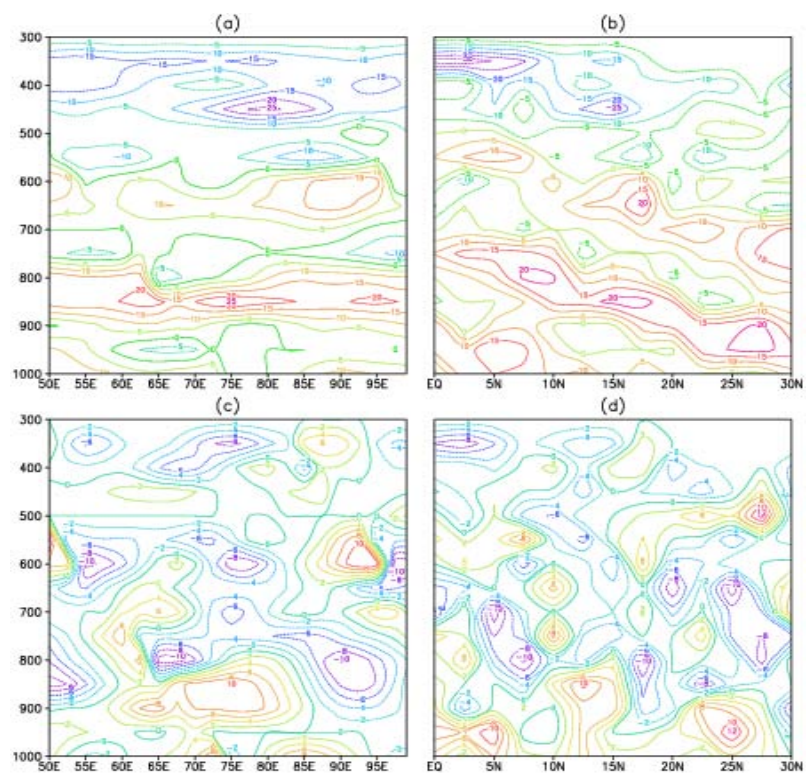

Figure 5: Vertical distribution of horizontal wind at $15^{\circ} \mathrm{N}$ (x-p plane) and $80^{\circ} \mathrm{E}$ (y-p plane), (a) and (b) for zonal wind, (c) and (d) for meridional wind for $26^{\text {th }}$ July 2005. 

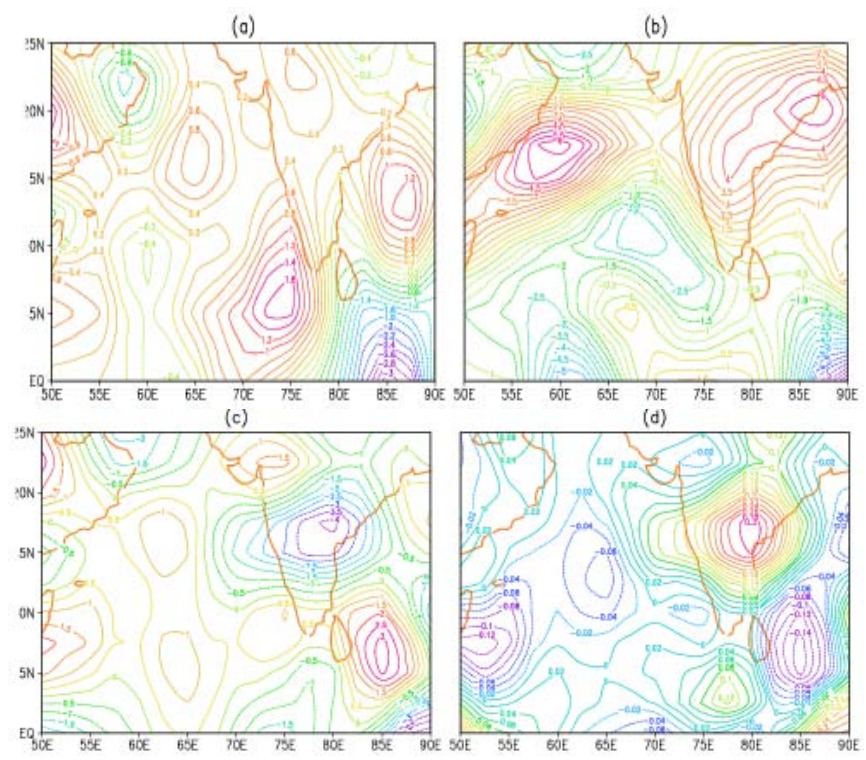

Figure 6: Horizontal distribution of (a) $\mathrm{D}\left(10^{-5} \mathrm{~s}^{-1}\right)$, (b) $\zeta\left(10^{-5} \mathrm{~s}^{-1}\right)$, (c) $\omega\left(10^{-3} \mathrm{hPa} \mathrm{s}^{-1}\right)$ and (d) $\mathrm{Q}_{\mathrm{H}}\left(10^{-1} \mathrm{~J} \mathrm{Kg}^{-1} \mathrm{~s}^{-1}\right)$ at $700 \mathrm{hPa}$ for $26^{\text {th }}$ July 2005 .

\section{Conclusions}

By examining the wind distribution in the 3-dimensional domain, it is found that strong vertical shear of zonal and meridional winds are present in both the cases of June and July. In addition to this, there exists strong meridional wind shear for the case of July. Intense magnitudes of meridional wind suggest the need of examination of necessary condition of baroclinic instability for combined zonal and meridional flow. All the computation show the atmosphere is highly unstable in the middle troposphere near 850-650 $\mathrm{hPa}$. Baroclinic instability condition is satisfied in the lower layer (below $800 \mathrm{hPa}$ ) for both June and July active monsoon days. Barotropic instability condition is satisfied by lower as well as upper troposphericc zonal flow, near peninsular region and near monsoon trough zone for the active monsoon period of June. For the case of July active period, the barotropic instability condition is satisfied near monsoon trough zone by lower and upper tropospheric flow but near peninsular region, the barotropic instability condition is satisfied only by upper tropospheric flow. Strong magnitudes of $\zeta, \omega$ and $\mathrm{Q}_{\mathrm{H}}$ for all the days in June and July are found and shown for the latitudinal belt $15 \mathrm{~N}-20 \mathrm{~N}$ in Table 1 ( $\mathbf{a}$ and b). Maximum intensity of vorticity $\zeta\left(6.5 \times 10^{-5} \mathrm{~m} \mathrm{~s}^{-1}\right)$ and vertical velocity $\omega\left(-6 \times 10^{-3} \mathrm{hPa} \mathrm{s}^{-1}\right)$ near $23^{\circ} \mathrm{N}, 68^{\circ} \mathrm{E}$ up to $400 \mathrm{hPa}$, indicates presence of active off shore trough, as a result of which very heavy rainfall occurred throughout the days. Cyclonic vorticity is signitificantly enhanced as compared to the climatological values. Further, it is found that cyclonic vorticity has deeper vertical extent upto $350 \mathrm{hPa}$ (figure not shown) which is in the close agreement with Dey et al. [4]. In view of the strong low level convergence in the boundary layer, intense upward motion and high intensity of the heat source in the mid troposphere together result that the growth of the system is due to (CISK) mechanism. Both the cases of
Table 1(a): $\zeta\left(10^{-5} \mathrm{~s}^{-1)}, \omega\left(10^{-3} \mathrm{hPa} \mathrm{s}^{-1}\right)\right.$ and $\mathrm{Q}_{\mathrm{H}}\left(10^{-1} \mathrm{~J} \mathrm{Kg}^{-1} \mathrm{~s}^{-1}\right)$ for the period $21^{\text {st }}-30^{\text {th }}$ Jun 2005

\begin{tabular}{|c|c|c|c|c|c|c|c|c|c|c|}
\hline Level & & & & & & & & & & \\
$(\mathrm{hPa})$ & 21 & 22 & 23 & 24 & 25 & 26 & 27 & 28 & 29 & 30 \\
\hline $\begin{array}{c}500 \\
\omega\end{array}$ & 0.2 & 0.1 & 0.1 & 0.4 & 0.4 & 1.4 & 1.7 & 1.3 & 0.6 & 1.0 \\
$\mathrm{Q}_{\mathrm{H}}$ & -2 & -5 & -7 & -7 & -4 & -3 & -6 & -6 & -6 & -2 \\
\hline 700 & 0.1 & 0.4 & 0.5 & 0.5 & 0.3 & 0.2 & 0.5 & 0.4 & 0.4 & 0.2 \\
\hline$\zeta$ & 4.5 & 5.5 & 5.5 & 4.5 & 4.0 & 5.5 & 5.5 & 5.5 & 6.5 & 5.0 \\
$\omega$ & -3 & -6 & -6 & -6 & -2 & -4 & -4 & -4 & -4 & -2 \\
$\mathrm{Q}_{\mathrm{H}}$ & .25 & 0.2 & 0.5 & 0.5 & .15 & 0.3 & 0.2 & 0.4 & 0.4 & 0.1 \\
\hline 850 & & & & & & & & & & \\
$\zeta$ & 5.5 & 6.5 & 5.5 & 4.0 & 3.5 & 4.5 & 4.5 & 5.5 & 6.0 & 5.5 \\
$\omega$ & -2 & -4 & -4 & -4 & -1 & -3 & -2 & -2 & -2 & -2 \\
$\mathrm{Q}_{\mathrm{H}}$ & 0.2 & 0.2 & 0.1 & 0.1 & 0.1 & 0.1 & 0.2 & 0.2 & 0.3 & 0.1 \\
\hline
\end{tabular}

Table 1(b): $\zeta\left(10^{-5} \mathrm{~s}^{-1)}, \omega\left(10^{-3} \mathrm{hPa} \mathrm{s}^{-1}\right)\right.$ and $\mathrm{Q}_{\mathrm{H}}\left(10^{-1} \mathrm{~J} \mathrm{Kg}^{-1} \mathrm{~s}^{-1}\right)$ for the period $22^{\text {nd }}-31^{\text {st }}$ Jul 2005

\begin{tabular}{|c|c|c|c|c|c|c|c|c|c|c|}
\hline $\begin{array}{c}\text { Date } \\
\text { Level } \\
(\mathrm{hPa})\end{array}$ & 22 & 23 & 24 & 25 & 26 & 27 & 28 & 29 & 30 & 31 \\
\hline 500 & & & & & & & & & & \\
$\zeta$ & 0.2 & 0.3 & 0.1 & 0.3 & 0.1 & 0.6 & 0.4 & 0.6 & 0.2 & 0.6 \\
$\omega$ & -2 & -3 & -2 & -3 & -1 & -3 & -3 & -2 & -2 & -1 \\
$\mathrm{Q}_{\mathrm{H}}$ & 0.2 & 0.2 & 0.2 & 0.2 & 0.4 & 0.2 & 0.3 & 0.2 & 0.3 & 0.2 \\
\hline 700 & & & & & & & & & & \\
$\zeta$ & 2.5 & 5.5 & 8.5 & 8.0 & 5.0 & 5.0 & 4 & 7.0 & 7.0 & 6.5 \\
$\omega$ & -2 & -2 & -2 & -3 & -4 & -4 & -5.5 & -3 & -4 & -4 \\
$\mathrm{Q}_{\mathrm{H}}$ & 0.2 & 0.1 & 0.1 & 0.1 & .1 & 0.3 & 0.2 & 0.1 & 0.2 & 0.2 \\
\hline 850 & & & & & & & & & & \\
$\zeta$ & 2.0 & 4.0 & 6.0 & 8.5 & 6.0 & 5.0 & 4.5 & 7.5 & 7.0 & 6.0 \\
$\omega$ & -1 & -1 & -2 & -2 & -2 & -3 & -2 & -2 & -3 & -2 \\
$\mathrm{Q}_{\mathrm{H}}$ & 0.1 & 0.1 & 0.1 & 0.1 & 0.1 & 0.1 & 0.1 & 0.1 & 0.1 & 0.1 \\
\hline
\end{tabular}

June and July have indicated that there exists the circulation in the presence of west coast monsoon onshore trough, Midtropospheric Super Cyclone (MTSC) over Gujarat and low level monsoon systems in the monsoon trough zone. Finally it can be concluded that there are few mesoscale systems embedded in the synoptic scale system that are already present in the large-scale monsoon circulation.

\section{Acknowledgements}

The authors are thankful to the Director, Indian Institute of Tropical Meteorology, Pune, for providing necessary facilities to carry out this research work and constant encouragement.

\section{References}

[1] R.Ananthakrishnan, M.K.Soman, "The onset of southwest monsoon over Kerala 1901-1980," International J. Climate, (8), pp 283-296, 1988. 
[2] P.V.Joseph, J.K.Eischeid, R.J.Pyle, "Interannual variability of the onset of the Indian summer monsoon and its association with atmospheric features El.Nino and sea surface temperature anomalies," Journal of Climate, (7), pp81-105, 1994.

[3] M.Rajeevan, S.Gadgil , J. Bhate, "Active and break spells of the Indian summer monsoon," J.Earth Syst.Sci., (119), pp229-247, 2010.

[4] Ayantika. Dey Chowdhury, R.Krishnan, "Dynamical response of the south Asian Monsoon trough to latent heating from stratiform and convective precipitation," J.Atmos.Sci., (68), pp1347-1363, 2011.

[5] A.K. Bohra, Swati Basu, E.N. Rajagopal, G.R. Iyengar, M. Das Gupta, R.Ashrit, B. Athiyaman, "Heavy rainfall episode over Mumbai on 26 July 2005," Current Science, (90), 9, pp 1188-1194, 2006.

[6] R.K.Jenamani, S.C.Bhan, S.R.Kalsi, "Observational/ forecasting aspects of the Meteorological event that caused record highest rainfall of $94.4 \mathrm{~cm}$ on 26-27 July 2005 in Mumbai," Current Science, (90), pp13441362, 2006.

[7] S.S.Vaidya, J.R.Kulkarni, "Simulation of heavy precipitation over Santacruz Mumbai on 26 July 2005 using mesoscale model," Journal of Meteor. Atmos. Phys., (98), pp55-66, 2007.

[8] B. Shyamala, C.V.V. Bhadram, " Impact of mesoscalesynoptic scale interactions on the Mumbai historical rain event during 26-27 July 2005," Current Science, (91), No.12, pp1649-1654, 2006.

[9] Y.V. Rama Rao, H.R.Hatwar, A.K.Salah, Y.Sudhakar, "An experiment using the high resolution Eta and WRF models to forecast heavy precipitation over India," Pure.Appl.Geophys., (164), pp1593-1615, 2007.

[10] A.Kumar, J.Didhia, R.Rotunno, D.Niyogi, U.C.Mohanty, "Analysis of the 26 July 2005 heavy rain event over Mumbai, India using the weather research and forecasting (WRF) model," Quar.J.R.Meteorol. Soc., (134), pp1897-1910, 2008.

[11] D.R.Sikka, P.S.Rao, "The use and performance of mesoscale models over the Indian region for two high impact events," Natural Hazards, (44), pp353-372, 2008.

[12] P.A Francis, S.Gadgil, "Intense rainfall events over the west coast of India." Meteorology and Atmospheric Physics, (94), pp27-42, 2006.

[13] U.S.De, S.Dutta, "West coast rainfall and convective instability," J.Indian Geophys. Union, (9), pp71-82, 2005.

[14] A.A.Ranade, N.Singh, "Large-scale wet spell and spatio-temporal rainfall extremes over India during 1951-2007," ISSN 0252-1075, Contribution from IITM, No. RR-126, 2010.

[15] C.S. Ramage, "Monsoon Meteorology," International Journal of Geophysics, (15), Academic Press, pp 296, 1971.
[16] E.Kalnay, M.Kanamitsu, et al., "The NCEP/NCAR 40year reanalysis project," Bulletin of the American Meteorological Society, (77), pp 437-471, 1996.

[17] J. O'Brien, "Alternative solutions to the classical vertical velocity problem," J.Atmos.Sci., (USA), (9), pp192-203, 1970.

[18] S..S.Naik, P.S.Salvekar, "Interannual variability in the dynamics and physics of the meanonset date of monsoon over Indian Region," Indian Journal of Radio and Space Physics. (33), pp 241-251, 2004.

[19] P.S.Salvekar, "On the development of monsoon disturbances through baroclinic instability and other physical processes," Ph.D. Thesis, University of Pune, 1984.

[20] P.K.Das, Monsoon, $5^{\text {th }}$ IMO Lecture No. WMO No.613, 1986.

[21] Mak Man-Kin, "The monsoonal mid-tropospheric cyclogenesis," Journal of Atmospheric Science, (32), pp 2246-2256, 1975.

[22] S.Moorthi, A.Arakawa, "Baroclinic Instability with cumulus heating," Journal of Atmospheric Sciences, (42), pp 2007-2031, 1985. 